\title{
A NOTE ON THE LIVERPOOL MEDICAL INSTITUTION
}

by

\section{G. SANDERSON}

DURING this Congress tribute has been paid to many of the men whose names are honoured in the medical history of Liverpool. To these must be added from the war memorial in the entrance hall, the name of Noel Godfrey Chavasse V.C. and bar, one of three men ever to win this double decoration. After Chavasse's death in 1917, the King said that the whole army would mourn the loss of so brave a brother; the MajorGeneral told how the entire battalion, smothered in mud and dropping with exhaustion paraded at his funeral; and a private soldier wrote that he was the bravest man in the world.

Since the year 1837, about a month before the accession of Queen Victoria, all these men have known the Institution, have spoken in its theatre, and have used its facilities and library. If it is true that Liverpool has made a worthwhile contribution to medical progress, it must be due in part to the exceptional, perhaps unique facilities provided by its Medical Institution.

The building is mainly due to the vision and energy of John Rutter, whose portrait adorns the lecture theatre. Who painted the portrait and why, is not known; possibly it was a local artist, Alexander Mosses. Rutter was a Quaker, a bachelor, and a man of simple and sober appearance. Of all the pictures in the Institution none looks less the fashionable physician. In 1837, at the age of seventy-five, he presided at the opening ceremony. He died in the following year, 1838, and was buried in an unmarked grave in the burial ground of the Society of Friends, and a tablet was erected to his memory in St. Peter's Church. All that remains of the church is the name Church Street in the heart of modern Liverpool, but when it was demolished in 1921 the memorial tablet was transferred and re-erected in the entrance hall of the Institution. Professor Strong translated it from the Latin as follows:

Sacred to the memory of JOHN RUTTER, M.D., who after a distinguished educational career at the Edinburgh Academy, practised successfully in this his native town for some fifty years. He passed away at last on 16th October 1838, in the 77th year of his age. His death was due to no disease, but to length of years alone. His character was simple, straightforward, guileless; his judgement was sure and far-seeing; his perseverance was great. The uprightness of his life and his professional skill alike won for him the love and admiration of all. To his relations he was most affectionate, a favourite with his friends. The skill wherewith nature had endowed him, and which study and varied experience had perfected, was at the free disposal of many friends. To the poor he gave his services freely. He was untiring in his endeavour to advance the study of good learning, in which his tastes were catholic and not commonplace.

President as he was of the Medical Society, by the unanimous vote of its members, he desired to see that Society housed in a stately habitation, and he aided it with money and advanced its progress by his patronage.

Unpretentious in his life, he made no enemies; he passed away in the midst of honourable toil; he left full many friends to mourn his loss. 


\section{G. Sanderson}

This monument was erected by a sorrowing sister to her brother, and by his surviving heirs to their respected uncle.

John Rutter was born in Liverpool in 1762. He graduated M.D. in Edinburgh in 1786 at the age of twenty-four, and published in Latin his thesis on 'Phthisis Pulmonalis'. Thereafter, he spent the rest of his professional and public life in Liverpool. He was the prime mover with William Roscoe, Dr. Currie and others, in founding the Athenaeum Club which opened in 1799, and during the next five years was successively treasurer, vice-president and president. He thus bequeathed to Liverpool two of its cultural institutions, and laid the foundations of two outstanding libraries.

In the year 1779, nearly sixty years before the opening of the Medical Institution, John Rutter at the age of seventeen attended a meeting at which the Liverpool Medical Library was publicly inaugurated with Dr. Matthew Dobson as its first President. It seems reasonable to suppose that this teenager was apprenticed to a local doctor. The library has been started some years previously, perhaps as early as 1770 , but 1779 is the year that is accepted as the original date of its foundation. For the next fifty years the library was housed either in the Infirmary or in the Church Street dispensary, but after 1827 the rapid growth of Liverpool involved the library in four removals in rapid succession. It was at this stage of crisis that the name of John Rutter, now the most senior and distinguished medical practitioner in the town, reappears on the presidential list. Coincidentally, Rutter was a president of the newly formed Liverpool Medical Society, and he was also a member of the first council of the Provincial Medical and Surgical Association founded in 1832, later to become the British Medical Association. Remember that he had helped to found the Athenaeum. Thus he had all the influence and experience to carry through this great undertaking which he envisaged in the words quoted by everyone who ever speaks or writes on this subject. In 1833, John Rutter wrote to William Squires, then president of the library 'It appears to me not at all improbable that the Corporation would provide the Library with accommodation at least equal to the present. But it appears to me that more accommodation is really wanted. Several gentlemen are of opinion, and I quite agree with them in this opinion, that it would be desirable to procure a building which would suffice for every purpose for which it could be required by the profession at large; that is to say in the first place for a Library, and secondly for all meetings of the profession, for Medical Lectures, or the meetings of Medical Societies; with a Committee-room annexed to it, with a convenient residence for a Librarian.' This was a remarkable vision, Rutter carried it through to a successful conclusion, and it has indeed sufficed for every purpose for which it could be required up to the present day.

The original plans of the Institution are still extant and were on exhibition during the Congress. Nothing is known of the architect, Clark Rampling, except his name. The exterior, with its colonnaded frontage of Storeton stone, is distinguished or forbidding as you care to regard it. It is only in recent years that a small name-plate has indicated its nature, and for many Liverpudlians it has been a somewhat mysterious place. Mr. Philip Hawe has drawn attention to a note in the Bickerton papers that there was at one time a popular belief that it was the place where, 


\title{
A Note on the Liverpool Medical Institution
}

incurable patients were suffocated. The lecture theatre is cosy, acoustically good and the roof lighting ensures the absence of any outside interruption with the exception of hailstones. Unfortunately neither the architect nor his successors have succeeded in solving completely the ventilation problems of this theatre where many generations of doctors have struggled to keep awake. The cost of the original building was a little over $£ 4,000$, and the subscriptions to the building fund are summarized as follows:

\begin{tabular}{lrrr} 
Medical men & 1592 & 19 & 0 \\
Bazaar & 1050 & 0 & 0 \\
Corporation of Liverpool & 1000 & 0 & 0 \\
Lay subscribers & 575 & 9 & 10 \\
\hline & $£ 4218$ & 8 & 10
\end{tabular}

Considerably more than half of the medical men residing in Liverpool and district were members of the Medical Institution when it was founded, and the London Medical Gazette in 1840 reported the position as follows:

\begin{abstract}
It may not be uninteresting to our readers to mention that a Medical Association, on an extensive scale, has been formed in the town of Liverpool, having for its object the advancement of medical science, and the cultivation of friendly intercourse amongst the members of the profession. A valuable medical library has existed above half a century in the town, and now contains many thousand volumes, and a Medical Society has also been for some years in active operation. The new Institution has arisen out of these, and already numbers 130 members. A short time ago the profession came forward liberally, and erected an elegant building on ground bestowed by the Corporation, containing under its roof the library, lecture and museum rooms, and a handsome room for the ordinary meetings of the association, which are held once a fortnight for carrying out the objects in view.
\end{abstract}

Few men have seen their aims so well fulfilled as John Rutter, and the building erected in 1837 has functioned satisfactorily to this day. However, in the post-war years it became clear that a growing membership (now exceeding 1,000) and still more a growing library, was placing an increasing strain on the accommodation. In particular the physical accumulation of books threatened to submerge it. There were books everywhere-in the corridors, on the back stairs, and lodging in the university and elsewhere. Three broad alternatives were considered. The first was to continue unchanged in a changing world, and this was attractive, not only because all change disturbs, but also because change here might have affected the whole character and atmosphere of the Institution. The second alternative was to concede that the Institution as a small and independent organization had outlived its usefulness, and time may yet show the soundness of this view. The third alternative, resolutely adopted in 1962 was to accept the challenge of the post-war era and to build an extension worthy of the city, of the medical profession and of its founder's vision of 'a building which would suffice for every purpose for which it could be required.'

Until 1960 there was a terrace of houses where the new extension now stands. Behind these houses was cottage property largely evacuated and falling into disrepair. The site itself had grown enormously in importance in the post-war years as a result of university developments, and the building of the Catholic Cathedral. Before the 


\section{G. Sanderson}

war the Institution stood at the corner of a street, whereas today it is at the gateway to the cultural precinct of Liverpool. Initially it was difficult to see how the whole area could be developed, but eventually this was achieved in collaboration with the Medical Insurance Agency and Lloyds Bank who between them tenant about half of the new building with the exception of the large basement bookstore. The new building cost $£ 70,000$ compared with John Rutter's $£ 4,000$, but as in 1837 the whole sum has been raised by the efforts of the medical profession and its friends. In 1964, in the course of these developments, the Institution received a Charter of Incorporation from Her Majesty the Queen.

The new extension was opened by H.R.H. Princess Margaret on 28 October 1966, and was one of those exceptional occasions when just about everything went right. The lecture theatre was filled to capacity, and Lord Cohen of Birkenhead, who acted as public orator, said of the work of the Institution that 'Here the opportunity has been offered to hundreds, nay thousands of doctors, to translate into practice Plato's dictum that education is a life-long business'. And of the library he said 'True, some libraries are bigger than ours, but very few have higher quality'; and he went on to parody Ben Jonson 'It is not growing like a tree, in bulk doth make a librarie'.

What of the future? Postgraduate education today is an 'in' subject, and new medical centres are growing up at a great rate in many parts of the country. To some extent these developments threaten the older foundations which cling to their independence and which are at some financial disadvantage compared with the newer sponsored centres. Nevertheless, the Institution has been able to take a leading part in postgraduate medical education, and in particular has pioneered in Liverpool successful meetings for general practitioners, although it has not so far found its place on the financial bandwaggon. There are now something like a hundred meetings of one sort and another held each year in its lecture theatre. Several times a year the Institution is honoured to entertain distinguished visiting societies such as the Eighth (1971) British Congress on the History of Medicine. Here, or from here, are organized the principal medical functions in the life of the city, including the Institution's inaugural meeting and presidential address, its annual dinner, the annual St. Luke's Day service, the joint meeting with the Manchester Medical Society, and an always enjoyable Christmas party. There is an active Ladies' Committee which arranges fund-raising activities and undertakes social work for the purpose of the Institution's Benevolent Fund. So as the Institution approaches the bicentenary which is due in 1979 it does so with the determination that it will continue its historic role as the centre of postgraduate medical activity in the Liverpool region. 


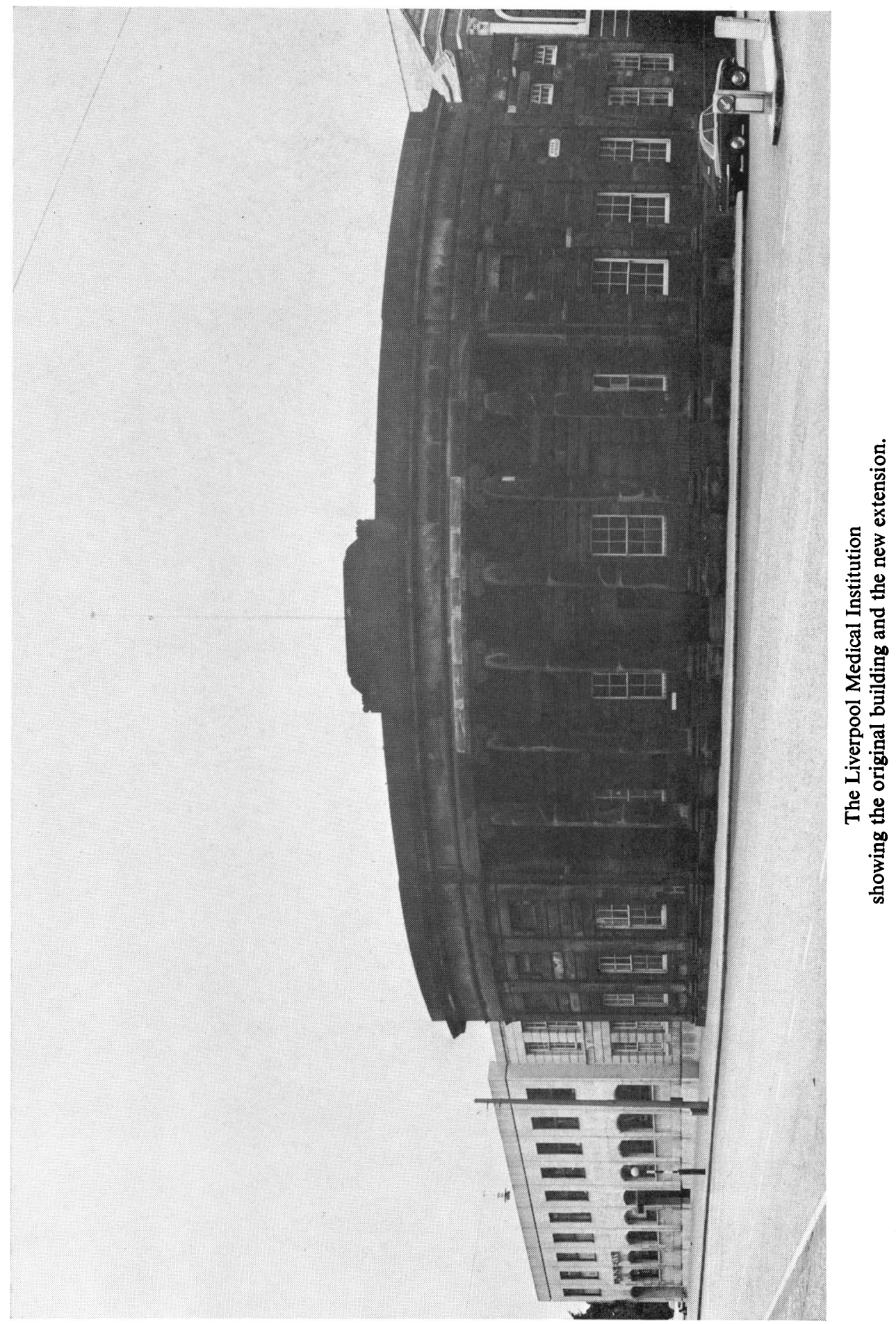

